\title{
FOSTERING ENTREPRENEURIAL MINDSET AT PONDOK HAJJAH NURIYAH SHABRAN DURING THE COVID-19 PANDEMIC
}

\author{
${ }^{1}$ Fathurrohman Husen, ${ }^{2}$ Fajar Santos \\ 1,2 UIN Raden Mas Said Surakarta
}

\begin{tabular}{l}
\hline ARTICLE INFO \\
\hline Article History: \\
Received March, 13, 2021 \\
Accepted June, 16, 2021 \\
Available June, 30 2021 \\
\hline
\end{tabular}

\section{Keywords:}

Entrepreneurship, Boarding School,

Covid-19

\begin{abstract}
Pemerintah menetapkan wabah Covid-19 sebagai bencana nasional sejak bulan Maret 2020. Pandemi merupakan kondisi yang tidak diharapkan dan harus direspons dengan cepat, tepat, dan tanggap sehingga tidak menimbulkan mudarat yang lebih buruk di masa sekarang maupun yang akan datang. Di antara dampak nyatanya adalah pada sektor ekonomi, baik menimpa secara perorangan maupun secara kelembagaan. Pondok Hajjah Nuriyah Shabran memiliki mahasiswa mondok dari berbagai daerah di Indonesia. Karenanya, perlu upaya untuk membentuk ketahanan ekonomi di lembaga tersebut, misalnya dengan berwirausaha. Wirausaha merupakan aktivitas yang tidak hanya berkaitan dengan untung-rugi dalam dunia bisnis. Lebih dari itu, mahasiswa mondok dapat menjadikan wirausaha sebagai upaya mengembangkan bisnis secara mandiri dan menjadi media dakwah bil-hal. Mindset tersebut perlu dibina dan dipahamkan kepada mahasiswa. Kegiatan pembinaan bertujuan untuk memberikan wawasan, arahan, dan motivasi kepada mahasiswa mondok di Pondok Hajjah Nuriyah Shabran tentang pentingnya berwirausaha dan korelasinya dengan dakwah sehingga mampu menghadapi Pandemi Covid-19 secara bijak, responsif, dan bernilai ibadah. Metode pembinaan dilakukan dengan cara ceramah dan diskusi aktif. Pembinaan diikuti oleh sepuluh mahasiswa mondok. Kegiatan berlangsung lancar dengan antusias peserta yang aktif bertanya sehingga tercipta suasana diskusi yang komunikatif. Tindak lanjut dari kegiatan pembinaan ini adalah perlu diadakan pelatihan atau pendampingan untuk memproduksi makanan atau barang yang terjangkau oleh mahasiswa mondok.
\end{abstract}

The government has designated the Covid-19 outbreak as a national disaster since March 2020. Pandemic is an unexpected condition and must be responded quickly, appropriately, and responsively so as not to cause worse harm in the present and in the future. Among the real impacts are on the economic sector, both individually and institutionally. Pondok Hajjah Nuriyah Shabran has mondok students from various regions in Indonesia. Therefore, it is necessary to make efforts to establish economic resilience in the institution, for example by entrepreneurship. Entrepreneurship is an activity that is not only related to profit-loss in the business world. Moreover, mondok students can make entrepreneurship as an effort to develop the business independently and become a medium of da'wah bil-hal. The mindset needs to be fostered and understood to students. The coaching activity aims to provide insight, direction, and motivation to students at Pondok Hajjah Nuriyah Shabran about the importance of entrepreneurship and its correlation with da'wah so as to be able to face the Covid-19 Pandemic wisely, responsively, and worth worship. The coaching method is done by means of lectures and active discussions. Coaching was followed by ten mondok students. The activity went smoothly with enthusiastic participants who actively asked questions so as to create a communicative discussion atmosphere. The follow-up of this coaching activity is that there needs to be training or mentoring to produce food or goods that are affordable to mondok students.

Address: L Building, Campus Sekaran, Gunungpati, Semarang,

Indonesia, 50229

Correspondent Address:

UIN Raden Mas Said Surakarta

Email: fath.husen@gmail.com 


\section{INTRODUCTION}

Pondok Hajjah Nuriyah Shabran is one of the Islamic institutions that provides dormitory facilities to students who receive scholarships at Muhammadiyah university of Surakarta. This cottage is a Waqf from Mrs. Hajjah Nuriyah Shabran which was inaugurated in 1983. The students who mondok are envoys from Muhammadiyah Regional Leaders/ Pimpinan Daerah Muhammadiyah (PDM) or Muhammadiyah Regional Leaders/ Pimpinan Wilayah Muhammadiyah (PWM) in Indonesia. This cottage collaborates with Muhammadiyah University of Surakarta in its formal education. Pondok Hajjah Nuriyah Shabran is a Muhammadiyah educational institution whose concepts and systems differ fundamentally from the pesantren system. Djazman Al-Kindi explained about the concept of the establishment of the cottage emphasizes the science of amaliah and scientific charity. Financing from education in Pondok Muhammadiyah is borne (scholarship) by the UMS campus on the mandate of the Central Leadership of Muhammadiyah, while the cost of living and daily life is handed over to PDM or PWM who send mondok students in Shabran or independent fees with the agreement of parents (Khoirudin \& Jamuin, 2020). Therefore, self-reliance is an urgent value instilled in students who mondok. Moreover, students who mondok expected to be able to become preachers or da'i in the wider community.

Among the types of entrepreneurship is the social entrepreneurship model. This type of entrepreneurship can also be done by students who mondok, where the mission is to be able to preach in the wider community. Social entrepreneurship can be a reflection of bil-hal da'wah. Understanding of social entrepreneurship as explained (Saragih \& Elisabeth, 2020) that the goal is to create profit and balance and positive impact on the social environment. In addition to creating an independent society, social entrepreneurship can trigger innovation and better economic change. Components that must exist in social entrepreneur activities include: innovation, opportunity, leadership, value creation, social benefit, and profitability.

In detail, innovation serves to create products or services that are socially accountable. Opportunity aims to see the opportunities resulting from important issues that exist in the community so that products and services can be utilized and affordable. Leadership aims to nurture social values in a better direction with the principle of community development. Value Creation aims to create transformations that lead to the solving of social problems of society. Social Benefit aims to create something realistic, affordable, and beneficial to society. Profitability aims to provide personal benefits while providing solutions to social problems that occur in society.
The Social Entrepreneurship model as described is suitable to be applied in the condition of the covid-19 pandemic. The current pandemic conditions have effects, such as rising unemployment and the increasing need for health protocol support products. This means that spontaneous transfer of work can be done from the number of terminations in the company to the production of health protocol needs entrepreneurially, such as producing masks and hand sanitizer.

For example, the manufacture of hand sanitizer independently can be done by students of SMK Negeri 4 Surabaya. In the journal of community service Educivilia (Utomo et al., 2020) explained about the activities of making hand sanitizer important to respond to its limited availability and soaring price. The surge in prices is caused by the massive number of people who buy the product to prevent the spread of covid-19.

Such activities are also carried out by (Armiani et al., 2020) namely mask making training in anticipation of the spread of covid-19 in Anyar Village, North Lombok Regency. In its activities, it is motivated by the importance of a serious response to the prevention of the spread of covid-19. In addition to the availability of medical masks that are increasingly rare in the market due to the high demand, the manufacture of cloth masks can be an alternative.

The two community service activities are certainly in accordance with the method of social entrepreneurship if directed to profit for the makers, in addition to providing social benefits, namely the creation of jobs, as well as preventing the spread of covid-19. Therefore, these production options can be reached by the general public.

In his research (Hariyanto, 2017) explained about the importance of fostering entrepreneurial spirit towards the independence of pesantren-based people. Considering, the character built in the world of pesantren is self-reliance, hard work, discipline, and honesty. The character supports entrepreneurial activities.

It is important to realize education that leads to a creative spirit, independent, and willing to find solutions to problems in the environment. Education that can make it happen among others with boarding schools (Rahmat, 2011). Education no longer learns about theory alone but also how to apply the theory to real life. Entrepreneurship is a way to address the competitive era that realizes educated human resources to move in the economic world of the people. Therefore, in addition to being built to be a da'i, mondok in Islamic institutions must also be equipped with entrepreneurial spirit.

In Islamic educational institutions, the ability to preach becomes an inherent vision and mission. Remember, da'wah is an obligation for Muslims and Muslims. The relationship of da'wah with 
entrepreneurship can be examined about the figure of the Prophet's friend, namely Abdurrahman bin Auf. Aizuddinur Zakaria in (Muliana, 2017) explained about the virtues of the Prophet Abdurrahman bin Auf's friend, among them is someone who has an entrepreneurial spirit and also a philanthropist. It is becoming rare nowadays that is full of worldly competition. The secret and method of Abdurrhman bin Auf in entrepreneurship as well as the implementation of Islamic understanding shows the values of da'wah delivered. Among others as follows:

1. Must have high confidence and independence. Including in terms of capital. Whatever capital he uses to start business activities / entrepreneurs, even has the principle not to receive large capital loans that actually cause laziness to him. Choosing market share also requires courage to analyze and determine what products are needed in the market.

2. Halal oriented in doing business, ranging from obtaining capital, process or production of goods or services, to sales (marketing). Of course this relates to the basic provisions of trade in accordance with the pillars and terms of Islamic greetings.

3. Creating a solid team, namely respecting employees and upholding the meaning of work with colleagues.

4. The belief system that Allah bestows sustenance for a merchant.

5. Export and Import. This activity is carried out on the sidelines of the obligation as a servant of Allah Almighty. namely by directly conducting business antra-city so as to indirectly expand the market share.

6. Quality of goods and services, such as transparency and honest action by explaining the products they sell openly so that it is known the advantages and disadvantages.

7. Maintain business relationship trust. For example, the quality of products sold and keeping the promise of payment are always maintained to avoid customer disappointment.

8. Diligently give alms. It is understood that wealth must be controlled so that one day when reckoned can be accounted for with alms (good value).

9. Life is simple and not sprees. It is shown by the difficulty of identifying that Abdurrahman ibn Auf was a rich man, because his simple appearance covered it.
The provisions of jurisprudence in the muamalat chapter, such as entrepreneurship and business, apply the principle of "Al-ashlu fii mu'amalati al-ibahah, illa maa yadullu dalil tahrimihi". That is, the origin of the law in peace (including entrepreneurship) is permissible, unless there are evidences that indicate its haraa. For example, it is forbidden because it does not meet the pillars and conditions are: Buying and selling illicit substances; Conditional trading; Buying and selling has an effect on madarat; Jua buy for being persecuted; Buy and sell something vague: muhaqalah (plants still in the rice fields); mukhadarah (still green and uncertain fruit); and trading and trading. Business activities that are prohibited because there are elements to harm others, among others: Buying and selling of people who are still in the offer; Trade by blocking trade outside the city/market; Buying trades with the intention of hoarding; Buying and selling loot (Ghazaly et al., 2015).

In conducting entrepreneurship near the dean of buying and selling activities, explained about the pillars and conditions as follows (Anwar, 2010).

Table 1

Pillars and Terms of Sale and Purchase Agreement

Terms
Aqil and puberty as well as different people
Statement/Understanding of attitudes and conditions
Certainty of existence, can be utilized, belongs to a
person, submitted according to the agreement
Clearly the amount, the payment method is clear, not
the exchange of illicit goods

The hope of this activity, mondok students can be motivated and understand that in addition to preaching in the assembly of science, entrepreneurship can also be the media, especially during the Covid-19 pandemic that has not ended until this moment, so that entrepreneurial activities conducted by mondok students can be an alternative to economic resilience

\section{METHOD}

Faculty of Ushuluddin and Da'wah IAIN Surakarta has a community service program every year. In 2020, the theme raised is related to strengthening the impact of Covid-19, especially the Da'wah Management Program raised the theme of strengthening economic resilience based on boarding schools. In this case the author becomes the party appointed to conduct community service activities.

Preparations were made for the implementation of this community service program, the author confirmed the builder of the cottage, namely Ustaz Rahmat Hamzah. The author confirms the condition of the cottage and the status of students who are still in the dormitory during the Covid-19 pandemic in June 2020. Finally, it was confirmed that there are nine students 
who still live in the dormitory and one cottage builder who can participate in community service activities. Technical constraints when the activity is not so significant related to the implementation of health protocols during the activity, namely with the use of masks, maintaining sitting distance, and the use of hand sanitizer when entering the room.

The activity was conducted on Tuesday, June 23, 2020. The implementation was conducted in the meeting room of Pondok Hajjah Nuriyah Shabran on the 1st floor, located at Saripan, Makam Haji, Kartasura, Sukoharjo, Central Java. The method used in community service is the method of lectures and discussions (question and answer). The author conducted a pretest and posttest to measure the success of entrepreneurial mindset mentoring activities at Pondok Hajjah Nurriyah Shabran during the covid-19 pandemic.

\section{RESULTS AND DISCUSSIONS}

The author conducted a pretest and posttest to measure the success of entrepreneurial mindset mentoring activities at Pondok Hajjah Nurriyah Shabran during the covid-19 pandemic. The author pretests the participants' understanding before fostering an entrepreneurial mindset to realize economic resilience during the pandemic, as well as its correlation with da'wah. Among other things, understanding of the rules of jurisprudence in doing business, here are the survey data related to participants' knowledge about the rules of jurisprudence in business. The survey was conducted by selecting the answer 'Yes, know' or 'Do not know' for the statement 'I already know the rules of jurisprudence in business'. Result:

Table 2

Participant's Response to Understanding Fiqh Rules in Business

\begin{tabular}{ccc}
\hline No. & Category & Percentage \\
\hline 1. & Know & $40 \%$ \\
2. & Not knowing & $60 \%$ \\
\hline Total & & $100 \%$ \\
\hline
\end{tabular}

Based on the data, shows that $60 \%$ or the majority of participants do not know the rules of jurisprudence in business or entrepreneurship. The data shows the need for this community service activity. The author also explored data related to the knowledge of participants who follow the coaching based on insights related to business strategy or entrepreneurship conducted by the Prophet's friend, Abdurrahman bin Auf. Result:

\section{Table 3}

Participant's Response to Abdurahman bin Auf's Business Concept

\begin{tabular}{ccc}
\hline No. & Category & Percentage \\
\hline 1. & Know & $20 \%$ \\
2. & Not Knowing & $70 \%$ \\
3. & No Answer & $10 \%$
\end{tabular}

Total $100 \%$

The data shows that the lack of understanding and knowledge about the figure of Abdurrahman bin Auf. Therefore, the material presented about business methods and strategies or entrepreneurship to students mondok important to build a mindset that the importance of entrepreneurship is not only to seek profit but also the mission of da'wah and spread goodness.

\section{Figure 1}

Photo of the author's activity when presenting coaching materials

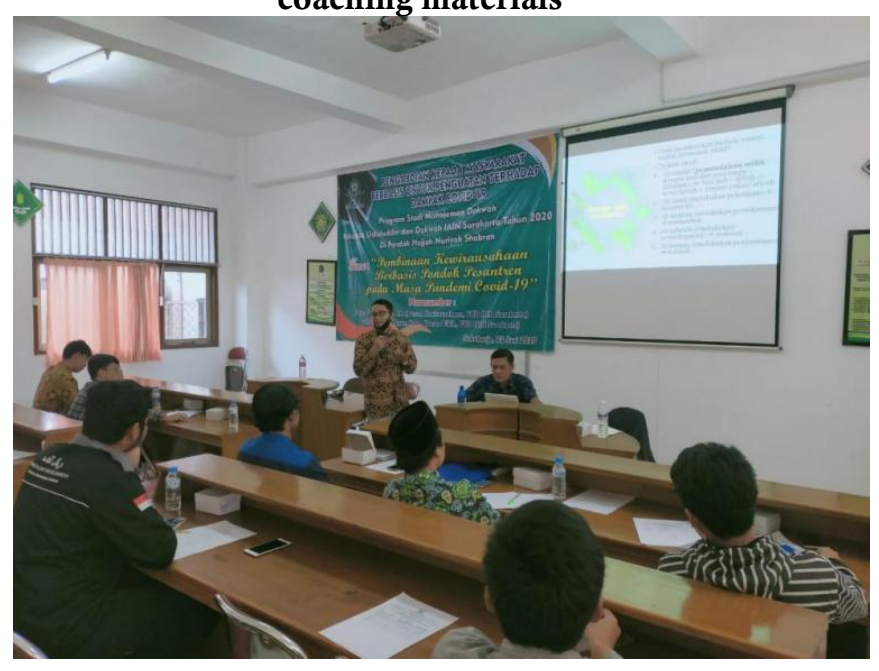

Mindset, in English translates as mindset. In Wikipedia it is explained about the definition of mindset is:

A mindset is a set of assumptions, methods, or notions

held by one or more people or groups of people.

That is, a mindset is a set of assumptions, methods, or ideas held by one or more people or groups of people. The material delivered in the community service program with the theme of economic resilience based on boarding schools is divided into two sessions. Each delivered 60 minutes per session so that a total of 120 minutes. The materials presented include the basics of entrepreneurship during the Covid-19 pandemic, including: motivation, fiqh perspective, and correlation with Islamic da'wah so as to realize a comprehensive mindset. Material 1 was delivered by Fajar Santoso and Material 2 was delivered by Fathurrohman Husen. Details of its activities as follows:

1. Presenter 1 delivers on the basics of entrepreneurship.

2. Presenter 1 conveys about a sure business mindset is good at following trends and will exist in the future.

3. Presenter 1 conveys the importance of abstinence and is ready for failure.

4. Presenter 1 tells about the business opportunities that can be done by mondok students during the covid-19 pandemic.

5. Presenter 2 conveys about the potential of da'wah that can be done by entrepreneurship. 
6. Presenter 2 conveys about the rules of flexibility in fiqh muamalat.

7. Presenter 2 conveys the principles of covenants in Islam.

8. Pemateri 2 conveys about the trading tips Abdurrahman bin Auf the father of business in Islam.

9. After the exposure of the two presenters held a discussion with the question and answer method. The author conducted a Post Test after conducting entrepreneurial coaching at Pondok Hajjah Nuriyah Shabran during the covid-19 pandemic. The question presented is about the usefulness of material about sharia business as the value of da'wah. The answer chosen is 'Helpful' or 'No/Less Helpful'. The survey results obtained as follows data,

\section{Table 4}

Participant's Response to The Benefits of Activities

\begin{tabular}{ccc}
\hline No. & Category & Percentage \\
\hline 1. & Useful & $80 \%$ \\
2. & No/Less Useful & $0 \%$ \\
3. & No Answer & $20 \%$ \\
\hline Total & & $100 \%$
\end{tabular}

Based on the data, the author concluded that participants who follow the entrepreneurial mindset coaching at Pondok Hajjah Nuriyah Shabran during the covid-19 pandemic can receive material and motivated to be entrepreneurial. The hope of this useful material assessment is that participants have a mindset that mondok students are also able to be entrepreneurial while conveying the values of Islamic da'wah

\section{CONCLUSION}

Entrepreneurial mindset development activities in hajjah Nuriyah Shabran hut during the Covid-19 pandemic are well underway. Activities can be carried out by applying health protocols, such as: keeping a distance, wearing a mask, and wearing a hand sanitizer. There must be a few obstacles related to the gathering of community service participants, but it can be met the quota of 10 participants. Coaching is carried out by the method of lectures and discussions, as a result of enthusiastic participants and understand the material presented, proven in the survey, the majority of participants who answered do not know the method of entrepreneurship ala Abdurrahman bin Auf and do not yet know the rules of jurisprudence in entrepreneurship. Survey $80 \%$ of participants stated that this activity is useful, showing the success and delivery of entrepreneurial mindset coaching materials. Hopefully, mondok students can be motivated and understand that in addition to preaching in the assembly of science, entrepreneurship can also be the media, especially during the Covid-19 pandemic that has not ended until this moment, so that entrepreneurial activities conducted by mondok students can be an alternative to economic resilience.

\section{REFERENCES}

Anwar, S. (2010). Hukum Perjanjian Syariah: Studi tentang Teori Akad dalam Fikih Muamalat. PT RajaGrafindo Persada.

Armiani, S., Fajri, S. R., Sukri, A., \& Pidiawati, B. Y. (2020). Pelatihan Pembuatan Masker Sebagai Upaya Antisipasi Penyebaran Covid-19 di Desa Anyar Kabupaten Lombok Utara. Jurnal Pengabdian UNDIKMA, 1(1), 22-27. https://doi.org/10.33394/jpu.v1i1.2550

Ghazaly, A. R., Ihsan, G., \& Shidiq, S. (2015). Fiqh Muamalat (3rd ed.). Kencana.

Hariyanto, R. (2017). Menumbuhkan Semangat Wirausaha Menuju Kemandirian Ekonomi Umat Berbasis Pesantren (Studi Kasus di PP Darul Ulum Banyuanyar Pamekasan). NUANSA: Jurnal Penelitian Ilmu Sosial Dan Keagamaan Islam, 14(1), 185.

https://doi.org/10.19105/nuansa.v14i1.1318

Khoirudin, A., \& Jamuin, M. (2020). Kontinuitas dan Diskontinuitas Pendidikan Kader Pondok Hajjah Nuriyah Shabran (1982-2014). Jurnal Muhammadiyah Studies, 1(1), 106-126. https://doi.org/10.22219/jms.v1i1.11412

Muliana, M. (2017). Konsep Dakwah Entrepreneur Menurut Abdurrahman Bin Auf. Al-Idarah: Jurnal Manajemen Dan Administrasi Islam, 1(2), 227. https://doi.org/10.22373/al-idarah.v1i2.2673

Rahmat, A. (2011). Pendidikan Berwawasan Kewirausahaan pada Usia Dini. Pedagogika, 2(1).

Utomo, A. P., Primaningtyas, W. E., Ahmad, M. M., Kusminah, I. L., Andiana, R., Nindyapuspa, A., Tjahyonowatie, S., \& Ningrum, D. S. (2020). Pelatihan Pembuatan Hand Sanitizer dan Aplikasi Pola Hidup Bersih di SMK Negeri 4 Surabaya dalam Upaya Menyikapi Pandemi COVID-19. Educivilia: Jurnal Pengabdian Pada Masyarakat, $1(2), \quad 111$. https://doi.org/10.30997/ejpm.v1i2.2941 